
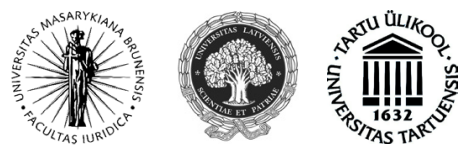

\title{
PRACTICE OF CHINA'S ENCOURAGEMENT ON CAPITAL EXPORT AND IT'S PROTECTION UNDER INTERNATIONAL INVESTMENT LAW: LITHUANIAN CASE
}

\author{
Andrius Bambalas \\ Mykolas Romeris University, Faculty of Law, \\ Institute of International and EU Law \\ Ateities 20, LT-08303 Vilnius, Lithuania \\ Telephone (+370 5) 2714669 \\ E-mail: andrius.bambalas@gmail.com
}

Received on 14 May, 2013; accepted on 26 June, 2013

doi:10.13165/JUR-13-20-2-21

Abstract. There are various notions of capital, but in this article movement of capital is being analysed from the perspective of international investment law - a country has an asset, which it cannot exploit or do so efficiently and there is a foreigner who possesses financing, technology or know-how, which allows to develop such asset. Lithuania is a net importer of capital, thus this article analyses on what might be the asset that Lithuanian government is interested in developing through foreign investment and why Lithuania does not develop such asset through other means, i.e. borrowing. As China is one the biggest capital exporters and becomes one of the biggest outward investors, this article also analyses driving factors behind such increase of outward investment from China - the Going Out policy and various instruments used by China to encourage such policy. Finally, the article analyses the possible underlying reasons Chinese company CAMCE has in Kaunas free economic zone and what such interest means under international investment law.

Keywords: capital export, outwards foreign investment, China, Going Out policy, international investment law. 


\section{Introduction}

Since the start of 1980s, when People's Republic of China (hereinafter - China) qualified as one of the world's twenty least developed countries till now when China overtook the EU as the second biggest economy ${ }^{1}$, China has undergone a dramatic transformation. Due to huge trade surplus, China actively engages into capital export. Part of it is a Go Out Policy, which was initiated in 1999 by the Chinese government to promote Chinese investments abroad.

Moreover, considering three recent economic disasters that affected mostly the developed countries and plagued Europe in particular since 2007, namely financial crisis of 2007-2008, global recession of 2009 and ongoing European sovereign-debt crisis, the capital flows changed from North-South ${ }^{2}$ direction to South-South or even South-North. As the hostility towards Chinese investments in the USA persists ${ }^{3}$, it should not come as a surprise that the EU became the most important destination of China's overseas direct investment, which in 2012 increased to 12.6 billion USD, 21\% more than in $2011^{4}$. According to the survey of investment fund A CAPITAL 5 , the staggering $93 \%$ of all China's FDI were made by State Owned Enterprises (hereinafter - SOE) and only a fraction of $7 \%$ of all this amount was made by private companies.

On 24 April, 2013 the Ministry of Economy of the Republic of Lithuania (hereinafter - Ministry of Economy) announced ${ }^{6}$ about the memorandum between Kaunas Free Economic Zone (hereinafter - Kaunas FEZ) and China CAMC Engineering Co. Ltd. (CAMCE), a subsidiary of SINOMACH (China National Machinery Industry) Corporation, the largest machinery manufacturer in China. It was indicated that the CAMCE is interested in participation of construction and financing of multi-purpose transhipment and warehousing complex, which will form a part of Kaunas public logistics centre. Moreover, the Ministry of Economy announced that on 25 April, 2013 the minister of Economy was going to meet with the Minister of Commerce of China and discuss the bilateral trade and economic cooperation. On 25 April, 2013 the main business newspaper in Lithuania Verslo Žinios provided more details on this ordeal, indicating that the CAMCE had a strong support of China's government and that the

1 OECD, Economic Surveys CHINA, March 2013, Volume 2013/4, p. 10. [interactive]. [accessed on 20-052013]. <http://www.keepeek.com/Digital-Asset-Management/oecd/economics/oecd-economic-surveyschina-2013_eco_surveys-chn-2013-en>.

2 "North" means a developed country, "South" - a developing one.

3 Research Note, Chinese Investments: Europe vs. the United States [interactive]. [accessed on 22-052013]. <http://rhg.com/notes/chinese-investment-europe-vs-the-united-states $>$.

4 Nice to See You, EU. The Economist. 20 April, 2013. Citing investment fund A CAPITAL.

5 Capital Dragon Index [interactive]. [accessed on 20-05-2013]. <http://www.acapital.hk/dragonindex/A CAPITAL_DRAGON_INDEX_FY_2012_ENG.pdf>

6 News Announcement. Atverti Keliai Kinijos Kompanijoms Isikurti Kauno LEZ [interactive]. [accessed on 18-05-2013]. <http://www.ukmin.lt/web/lt/naujienos/naujienos/atverti_keliai_kinijos_kompanijoms_ isikurti_kauno_lez>. 
memorandum of intent was signed not only by the CAMCE and Kaunas FEZ, but by the minister of Economy, too ${ }^{7}$.

Such news raises various questions, such as how it is related to capital outflows from China and China's Going Out Policy, what might be the rationale behind such actions of the Lithuanian government, and why Chinese State Owned Enterprise might be interested in investing in Lithuania at all.

To the best knowledge of the author, Lithuanian scholars have never done an analysis on reasons for China's capital exports, meaning of Going Out Policy, attractiveness of Lithuania for China's capital exports, reasons of government's interest in promotion of investment, or provided legal analysis of such capital exports from the point of view of international investment law. Two Lithuanian authors have analysed trends of capital export $^{8}$ or impact of foreign direct investments ${ }^{9}$, however, such analysis neither took in account the global and regional financial framework that affects flows of capital (financial crisis, global recession and sovereign debt crisis or data beyond the year of 2010), nor looked at particular rather than theoretical reasons foreign companies/ countries might be interested in investing in Lithuania, nor contained sufficient and sound scientific analysis on the issues ${ }^{10}$.

As international investment law is used in a negative sense, i.e. arbitrating against the state for damages caused by violating certain obligations towards investor or his investment, rather than in a positive sense, i.e. giving investor some positive rights that are respected, it is usually overlooked until it is too late. The consequences for such failure to give a good consideration about international investment law might be dire, e.g. on 5 October, 2012 the Republic of Ecuador was ordered to pay US investor Occidental Petroleum Corporation the record sum of USD 1.77 billion (USD 2.3 billion with interest) ${ }^{11}$ and the value of 10 biggest ICSID awards exceeds USD 6 billion ${ }^{12}$. Consequently, it is strongly advisable for the government, even at the outset of relations leading to foreign capital landing in Lithuania, to bear in mind the existence of obligations under international investment law. As law is the instrument, which can be used either as a tool to attract foreign capital (investment) or as a defence mechanism against the state,

$7 \quad$ Kauno LEZ Perspektyva - Kinų Pramoninis Miestelis. Verslo žinios. 2013, 79: 6.

8 Kozlova, A. Capital Export: Past and Trends. Proceedings of the 16th Conference for Junior Researchers „Science - Future of Lithuania“ [interactive]. [accessed on 01-06-2013]. <http://jmk.vvf.vgtu.lt/index. php/conference/2013/paper/view/69/112>.

9 Šečkute, L.; Tvaronavičius, V. Tiesioginių Užsienio Investicijų Baltijos Šalyse Tyrimas. Verslas: Teorija ir Praktika. 2007, 8(3): 153-160.

10 Although it is not the purpose of this article, the author is critical on the methodology and conclusions reached by both of these authors.

11 ICSID Case No. ARB/06/11, Occidental Petroleum Corporation v The Republic of Ecuador. Award. 5 October, 2012 [interactive]. [accessed on 11-06-2013]. <https://icsid.worldbank.org/ICSID/FrontServlet? requestType $=$ CasesRH\&action $V a l=$ showDoc\&docId $=$ DC2672_En\&caseId $=\mathrm{C} 80>$.

12 Largest Investor-State Awards 2001-2013. The American Lawyer [interactive]. [accessed on 1906-2013].<http://www.americanlawyer.com/PubArticleTAL.jsp?id=1371752894639\&slretu $\mathrm{rn}=20130618070934>$. 
it is important to understand the underlying reasons behind the rediscovery of China on the side of the Government of Lithuania and interest in Lithuania on the side of China.

This article is an initial research that focuses on these questions and the purpose of this article is three-fold. First, the purpose is to analyse the underlying transactions which constitute capital export and provide an overview on what are the possible reasons for the government of Lithuania to actively engage into seeking foreign investment (capital import) and why China, as a developing country, is interested in investing abroad, or in Lithuania in particular. Secondly, the purpose is to analyse how China supports its capital exports. The third aim is to assess recent news on potential exports of China's capital to Lithuania and evaluate such potential capital exports under international investment law.

\section{Why Lithuania imports and China exports capital?}

\subsection{Theoretical model of capital exports under international investment law}

Before going into analysis of "capital export", the definition of it should be presented. A capital is an elusive notion. It has different meanings varying from a stock of resources that may be employed in the production of goods and services to the human population; nonmaterial elements, such as skills, abilities and education; land, buildings, machines, equipment of all kinds and all stocks of goods - finished or unfinished - in the hands of both firms and households ${ }^{13}$.

International law does not regulate what the capital is, but it does regulate the flow of capital (movement of capital). The flow of capital is essentially regulated by five sets of instruments, each setting out slightly different rules, crafted on the underlying economic or legal perspectives specific to each treaty: 1) The Articles of Agreement of the International Monetary Fund; 2) multilateral and preferential agreements on services, such as the GATS and various free-trade agreements; 3) International investment agreements or bilateral investment treaties; 4) international financial regulations on capital adequacy (affects indirectly); 5) regional treaties, such as the European Union treaty, which require freedom of movement of capital as one of the "four freedoms" of the single market, or by wider regional agreements, such as the OECD Code of Liberalization of Capital Movements and the Code of Liberalization of Current Invisible Operations ${ }^{14}$. In this article, the "capital export" will be analysed through the economic and legal perspectives of international investment law.

13 On-line Encyclopaedia Britannica. Capital and Interest. [interactive]. [accessed on 02-06-2013]. <http:// www.britannica.com/EBchecked/topic/93850/capital-and-interest>.

14 Pasini, F.L. The International Regulatory Regime on Capital Flows. ADBI Working Paper Series No. 338, p. 4 [interactive]. [accessed on 28-05-2013]. <http://ssrn.com/abstract $=2065100>$. 
International investment law does not deal with capital directly because the underlying transaction that international investment law protects is between a foreign investor and a state. In international investment law, the word "capital" is used only in regard to "capital exporting states" and "capital importing states". "Capital exporting state" usually is a developed country, which has a high per capita income ${ }^{15}$, a high level of industrialisation and infrastructure, which nationals (usually companies) have acquired capital that can be exported. "Capital importing state" usually is a developing country, which tries to increase per capita income or country's standard of living through industrialization of the economy, development of infrastructure or by other means. Accordingly, the movement of capital (i.e. export or import of capital) occurs when a capital importing country (usually a developing country) has an asset, which it cannot exploit (or do so efficiently) by itself ${ }^{16}$ and there is a foreigner who possesses financing, technology or know-how, which allows to develop such an asset or develop it more efficiently ${ }^{17}$.

However, the existence of such preconditions does not necessarily mean that the movement of capital will occur. Each country is the sovereign over its territory, which means that the government of the country based on political or economic realities decides on its own path of development of economy. There is no international obligation requiring the state to commit to foreign capital (unless the state undertook such obligation under international law). Thus, while pursuing the development of country's standard of living, the government can decide to use exclusively its own capabilities (capital). Such self-sufficient or closed economy in terms of economic systems is known as autarky. A modern example of such self-sustainable economy is Democratic People's Republic of Korea.

However, when the state agrees to allow foreign capital to come (to import capital), the capital flows can start and transaction of moving such capital from the perspective of capital exporting state is regarded as the capital export, whereas from the perspective of capital importing state such transaction is the capital import.

Once the state decided to commit itself to foreign capital, it can do it in several ways. First of all, the state can borrow money (through aid, direct loans from other states or international institutions, issuing debt securities in capital markets, i.e. borrowing from individuals) and with such proceedings try to exploit or optimise exploitation of the asset it has. Secondly, the state can allow its domestic companies to get financing via foreign capital by allowing companies either to borrow abroad or allow foreign companies to participate in companies through equity (usually shares). Finally, the state might decide to exploit the asset through foreign direct investment, thus obtaining the financing, experience, technology, know-how from the foreign investor, while transferring the risk

15 GDP per capita is often considered as a basic indicator of a country's standard of living.

16 Assets are resources and capabilities capable of generating a future income stream, e.g. natural resources, un- or underdeveloped labour, infrastructure, etc.

17 The capital (assets or money) can flow out of a country due to an event of economic consequence, too. In economics, such phenomenon is known as capital flight. However, such situation is not relevant to international investment law and thus not analysed. 
of successful exploitation of the asset to the investor. Depending on the attractiveness of the asset, i.e. the profit the exploitation of such resource could bring to the investor, the range of actions the state might require to take varies from no action at all to a need of a special investment agreement between government and investor providing favourable non-market conditions for the foreign investor, e.g., Russian Federation has oil and gas deposits, therefore, notwithstanding to poor record on investment protection, foreign companies are eager to come into exploration of such natural resource. On the contrary, notwithstanding to the openness to capital flows and protection given to foreign investors, the Republic of Lithuania had to provide some undisclosed financial benefits to Barclays for establishment of its IT centre in Vilnius in 2009.

Such theoretical model on perspectives of international investment law over the capital flows indicates the framework, under which capital export is evaluated and protected under international investment law. However, this model and manner in which the government might commit to the foreign capital does not explain what transactions fall under the term "capital export".

As international investment law by itself does not provide such list, it is helpful to look at the definition of the capital provided in other fields that regulate the capital flows, namely EU Nomenclature of the Capital Movement annexed to the Council Directive 88/361/EEC and OECD Code of Liberalisation of Capital Movements. Under the Nomenclature of the Capital Movement annexed to the Council Directive 88/361/ $\mathrm{EEC}^{18}$, the capital comprises of foreign direct investment (FDI), real estate investment or purchases, securities investment, granting loans and credits and other operations with financial institutions. Under Annex A of OECD Code of Liberalisation of Capital Movements ${ }^{19}$, capital includes direct investment, building, purchase or sale in real estate, operations in securities on capital markets, operations on money markets, purchase, sale or exchange for other assets of domestic instruments and claims on financial market, purchase and sale of collective investment, securities, credits and loans, sureties, guarantees and financial back-up facilities ${ }^{20}$. As it can be seen, the government can borrow money or through regulation allow its domestic companies to borrow money (import capital) through various transactions. Foreign direct investment comes as a specific form of the capital export.

In fact, during the modern industrialisation of most of the world, which started after the end of the World War II, the majority of developing states and especially newly emerged former colonial countries were fiercely against foreign direct investment and thus financed their development through borrowing ${ }^{21}$. Foreign direct investment as a

18 Nomenclature of the Capital Movement Referred to in Article 1 of the Council Directive 88/361/EEC of 24 June 1988 for the implementation of Article 67 of the Treaty, [1988] OJ L 178, 08/07/1988 P. 0005 0018

19 OECD Code of Liberalisation of Capital Movements [interactive]. [accessed on 28-05-2013]. <http:// www.oecd.org/daf/inv/investment-policy/capital\%20movements_web\%20english.pdf>.

20 This list provided by the author is exemplary and not exhaustive. The complete definition of term "capital" in Annex A of OECD Code of Liberalisation of Capital Movement consists of 13 pages.

21 Sornarajah, M. The International Law on Foreign Investment. Third edition. New York: Cambridge University Press, 2012, p. 143. 
form of the capital export became increasingly popular only in the late 1980s. Such eventual acceptance of investment was determined by two events: firstly, collapse of the Soviet Union and impressive growth of economies of Japan, Honk Kong, South Korea, Singapore, Taiwan, Indonesia, Malaysia and Thailand, which freely accepted capital flows, convinced countries that market economy in general and capital flows in particular are essential for the successful development of the state. Secondly, the debt crisis of 1980s and extensive policies of borrowing by the United States left states without alternatives to foreign investment as the sources of capital ${ }^{22}$.

Considering such theoretical framework and previous practice of developing states, the question arises what are the current capital import trends in Lithuania and why the government of Lithuania actively seeks to attract foreign investment?

\subsection{Trends of capital import in Lithuania}

Lithuania is a developing state, which, according to the date of the central bank of Lithuania, continued to accumulate foreign direct investment at a steady pace. At the fourth quarter of 2012, the value of foreign direct investments in Lithuania was 41.163 billion LTL. ${ }^{23}$

Lithuania has never been a very active borrower of capital. However, a coincidence of the 2008 financial crisis and the 2009 global recession on the one hand, with Lithuanian policy to increase birth rate through additional financial benefits for new-borns (which started in 2008) on the other, created a need for the government to borrow. This need occurred due to the severe budget deficits of the Lithuanian State Social Insurance Fund Board of the Republic of Lithuania under the Ministry of Social Security and Labour (hereinafter - the Social Security Fund).

The Social Security Fund started to have a budget deficit in the year of $2008^{24}$. During the period of 2008-2012 the total deficit of the Social Security Fund budget reached 10.996 billion LTL. In 2008 the deficit was 1.5 billion LTL and it was caused mainly by the loss of taxes paid by employers, i.e. workers being laid off, and the increase in parental benefits ${ }^{25}$. In 2009 the Social Security Fund budget deficit was equal to 2.879 billion LTL, which occurred due to continuing tendencies of the previous year ${ }^{26}$. In 2010 the budget deficit was 2.707 billion LTL and the deficit decreased because the government decided to reduce payments on pensions due to economic hardship

22 Vandenvelde, K.J. A Brief History of International Investment Agreements. University of California at Davis Journal of International Law and Policy. 2005, 12: 157-194, p. 177-178.

23 Foreign Direct Investment According to Investor States [interactive]. [accessed on 03-06-2013]. <http:// www.lb.lt/stat_pub/statbrowser.aspx?group=8006\&lang=lt $>$.

24 Reports on Implementation of Budget [interactive]. [accessed on 03-06-2013]. <http://www.sodra.1t/lt/ veikla/biudzetas $>$.

25 Consolidated Financial Statement of the Social Security Fund for the Year 2008 [interactive]. [accessed on 03-06-2013]. <http://www.sodra.1t/get.php?f.4863>.

26 Consolidated Financial Statement of the Social Security Fund for the Year 2009 [interactive]. [accessed on 03-06-2013]. <http://www.sodra.lt/get.php?f.13484>. 
and implemented cuts on parental benefits ${ }^{27}$. In 2011 the Social Security Fund deficit decreased to 1.998 billion LTL, as the revenue from employment increased (more people were employed), however, more people started to claim unemployment benefits and payments on parental benefits were still substantial ${ }^{28}$. Finally, in 2012, notwithstanding to the increased revenue from employers and the decreased payments on parental benefits due to the ruling of the Constitutional Court, the government had to reinstate full payment on pensions, therefore, the Social Security Fund deficit decreased by a fraction to 1.912 billion LTL. As the Social Security Fund had minor budget surpluses prior to 2008, the Lithuanian government had to finance only 9.727 billion deficit of the Social Security Fund ${ }^{29}$.

Moreover, the collapse of two local banks added an additional 3.85 billion LTL pressure on the government of Lithuania: in 2011 the government had to lend 2.979 billion LTL interest free loan to State Undertaking "Deposit and Investment Insurance" (727 million LTL was returned on 2012) in order to assist compensation to the depositors of the bank SNORAS ${ }^{30}$ and agreed to give an additional 800 million LTL 2.801 per cent loan to finance transfer of property, rights, contracts and obligations of the Ukio bank ${ }^{31}$.

Consequently, the government of Lithuania plans to have a budget deficit of 2.7 billion LTL in $2013^{32}$. In order to finance such spending, the government of Lithuania borrows money. As of 31 March, 2013, the debt of the government of Lithuania is equal to 47.903 billion LTL, which is mainly owned to foreign debtors (34.483 billion LTL) ${ }^{33}$. According to the Ministry of Finance, by the end of the year 2013 the public debt of Lithuania will be equal to 39.2 per cent of $\mathrm{GDP}^{34}$. Compared to other EU member states, Lithuania has one of the smallest public debts compared to GDP.

As borrowing is one of the forms of the capital import that finances the development of the economy of Lithuania and the government is not heavily indebted, the question arises why the government of Lithuania actively seeks to attract foreign investors instead of continuing the borrowing? The answer may lay in politics.

27 Consolidated Financial Statement of the Social Security Fund for the Year 2010 [interactive]. [accessed on 03-06-2013]. <http://www.sodra.lt/get.php?f.20574>.

28 Consolidated Financial Statement of the Social Security Fund for the Year 2011 [interactive]. [accessed on 03-06-2013]. <http://www.sodra.lt/get.php?f.23319>.

29 Statistical Data Portal [interactive]. [accessed on 03-06-2013]. <http://atvira.sodra.lt/>.

30 Deposit and Investment Insurance of 2012. Financial Statement of State Undertaking [interactive]. [accessed on 05-06-2013]. <http://iidraudimas.lt/uploads/documents/Metine_finansine_2012_2.pdf>.

31 Resolution No. 153 of the Government of the Republic of Lithuania on Financing the Participation of State Undertaking "Deposit and Investment Insurance" in Transfer of Assets, Rights, Contracts and Obligations of the Bank, dated 20 February 2013. Official Gazette. 21 February, 2013, No. 20-966.

32 Official Notice of the Ministry of Finance [interactive]. [accessed on 28-05-2013]. <http://www.finmin.lt/ web/finmin/2013_biudzetas/skolinimasis $>$.

33 Ministry of Finance of the Republic of Lithuania. General Government Debt by Type of Debt Holder [interactive]. [accessed on 28-05-2013]. <http://www.finmin.lt/finmin.lt/failai/deficitas/2013/2013IQGG kred.pdf $>$.

34 Supra note 32. 
The most important political factor is Euro. According to the Government Programme $2012^{35}$, preparation to adopt the euro and to become a full member of the Euro zone is an urgent priority of the government, which is beneficial for the state and the development of economy. Moreover, as Estonia adopted the euro in 2011 and Latvia is planning to adopt it from 1 January, $2014^{36}$, there is an additional pressure for Lithuanian politics to have the euro as soon as possible. The government has already started to prepare plans for the adoption of the euro in 2015 and on 30 May, 2013 during a radio interview the prime minister of Lithuania has announced that there is $95 \%$ chance that Lithuania will have the euro in 2015.

In order to adopt the euro, the state has to meet euro convergence criteria (Maastricht criteria). The most relevant euro convergence criteria for Lithuania are the government budget deficit, which cannot exceed 3 per cent of GDP, and the overall government debt to GDP ratio, which cannot exceed 60 per cent.

The Social Security Fund budget deficit negatively affects the overall deficit of the budget of the government (in 2012 it constituted 1.7 per cent of GDP). ${ }^{37}$ However, as the biggest expenditure of the Social Security Fund goes to pensions (72.5 per cent in 2012), which affected 601.6 thousand recipients of pensions at the end of $2012^{38}$, considering that they constitute 23 per cent of all electorate ${ }^{39}$ and elderly people are more prone to participate in elections, it should not come as a surprise that one of the goals of the government is not to cut pensions or other social benefits, but rather increase the revenue of the Social Security Fund ${ }^{40}$.

Taxes paid by employers are the biggest source of income for the Social Security Fund and constituted $73.6 \%$ of all the income in $2012 .{ }^{41}$ Although Lithuanian unemployment rate is not as high as in infamous Spain or Greece, the official rate of unemployment is still high. It varies from 12.5 per cent based on Eurostat data of April, $2013^{42}$ to 11.5 per cent based on the newest report of Lithuanian Labour Exchange under the Ministry of Social Security and Labour ${ }^{43}$. 11.5 per cent of the unemployed constitutes an asset of 213400 people that Lithuania cannot effectively exploit.

35 Articles 34 and 50, Resolution No. XII-51 of the Seimas of the Republic of Lithuania on Programme of the Government of Lithuania, dated 13 December 2012. Official Gazette. 20 December 2012, No. 149-7630.

36 Press Release. Commission concludes that Latvia is ready to adopt euro in 2014. [interactive]. [accessed on 04-06-2013]. <http://europa.eu/rapid/press-release_IP-13-500_en.htm?locale=en>.

37 The Borrowing of Governmental Sector, Maastricht Criteria [interactive]. [accessed on 30-05-2013]. $<$ http://www.finmin.lt/finmin.lt/failai/deficitas/2013/PDP2012koreg.pdf $>$.

38 Supra note 29.

39 There were 2,588,418 voters in 2012 parliamentary elections. [interactive]. [accessed on 05-06-2013]. $<$ http://db1.stat.gov.lt/statbank/selectvarval/saveselections.asp?MainTable=M3220101\&PLanguage $=0 \&$ TableStyle $=\&$ Buttons $=\&$ PXSId $=20673 \& I Q Y=\& \mathrm{TC}=\& \mathrm{ST}=\mathrm{ST} \& \mathrm{rvar} 0=\& \mathrm{rvar} 1=$ \&rvar $2=\& \operatorname{rvar} 3=\& \mathrm{rvar} 4$ $=\& \operatorname{rvar} 5=\& \operatorname{rvar} 6=\& \operatorname{rvar} 7=\& \operatorname{rvar} 8=\& \operatorname{rvar} 9=\& \operatorname{rvar} 10=\& \operatorname{rvar} 11=\& \operatorname{rvar} 12=\& \operatorname{rvar} 13=\& \operatorname{rvar} 14=>$.

$40 \quad$ Supra note 35 , Article 54.

41 Supra note 29.

42 EUROSTAT Unemployment News Release April 2013 [interactive]. [accessed on 03-06-2013]. <http:// epp.eurostat.ec.europa.eu/cache/ITY_PUBLIC/3-31052013-BP/EN/3-31052013-BP-EN.PDF>.

43 Lietuvos Darbo Rinka 2013/04 [interactive]. [accessed on 04-06-2013]. <http://www.ldb.lt/Informacija/ DarboRinka/Publikacijos/Attachments/2943/LIETUVOS\%20DARBO\%20RINKA\%202013-04.pdf>. 
As foreign direct investment can have either direct impact on employment (creation of new working places in case of greenfield investment) or incidental impact on employment (through horizontal or vertical spillovers) 44 $^{44}$ the government is particularly interested in the creation of new working places, which can ease the financial burden of financing the Social Security Fund budget deficit through employer taxes. This might explain the lengths the Lithuanian government goes in order to attract foreign investments in Lithuania. But the question arises what would be the reasons for China to export capital? This is dealt with in the next sub-chapter.

\subsection{Why does China export capital?}

China is a developmental state, which is a term used by international political economy scholars to refer to the phenomenon of state-led macroeconomic planning in East Asia in the late twentieth century. A classical example of developmental state is Japan, which was raised from the ruins of the Second World War into economic super power in the late 1980s. Although the development is the top goal of the state, one of the most important features of the developmental state, according to John Rapley, is that the state guides the market extensively, exercising strict control over investment flows using multifaceted import restrictions, regulating the terms of interaction between industry and agriculture, alerting the incentive structure of the economy, promoting technological change and protecting selected infant industries. ${ }^{45}$

Trade surplus allowed China to accumulate budget surpluses (through taxation) and huge foreign reserves of mainly US government bonds (through currency intervention). On the one hand, it gave China the means to actively support outward foreign investment of its companies; on the other hand, it encouraged the creation of Chinese sovereign wealth funds. Sovereign wealth funds are entities that manage the national savings for the purposes of investment ${ }^{46}$.

In 2000, as part of its tenth Five-Year Plan, China's central government formally announced the "Going Out" strategy ${ }^{47}$. Through the "Going Out" policy, China seeks to complement required resources, stimulate the export of goods and services and nurture its multinational companies and brands by encouraging companies to invest abroad, establish factories or buy property ${ }^{48}$. Support for local companies was

44 Dunning, J.H. and Lundan, S.M. Multinational Enterprises and the Global Economy. Second edition. Cheltenham: Edvard Elgar Publishing Limited, 2008, p. 315.

45 Rapley, J. Understanding Development: Theory and Practice in the Third World. Third edition. London: Lynne Rienner Publishers, Inc., 2007, p. 140.

46 The analysis on China's Sovereign Wealth Funds as a form of China's capital export and its potential significance shall be covered in a forthcoming article.

47 Chinese Outward Investment: An Emerging Policy Framework. A Compilation of Primary Sources, p. 2 [interactive]. [accessed on 25-05-2013]. $<\mathrm{http} / /$ www.iisd.org/pdf/2012/chinese_outward_investment. pdf $>$.

48 Better Implementation of the "Going Out" Strategy. Announcement of the China's State Council of 15 March 2006 [interactive]. [accessed on 07-06-2013]. <http://translate.google.lt/translate?sl=zh-

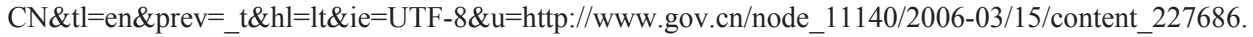
htm>. 
particularly important because while joining WTO, China undertook an obligation to open up its domestic market. Such opening of domestic market in effect means that goods and services of local Chinese companies will have to compete with world-class competitors. In order to ensure the continuous development and avoid the collapse of local production, China decided to support national champions and internally restructure low-end industry.

The national champions are sophisticated, high value-added companies, which are encouraged to create brand names and become globally competitive. Examples of the national champions are Huawei Technologies Co. Ltd. (telecommunications and networking equipment), ZTE Corporation (telecommunications equipment), China Petrochemical Corporation (Sinopec Group), China Ocean Shipping (Group) Company (shipping and logistics services supplier), Geely (car manufacturing, which acquired Volvo of Sweden), Lenovo (computers, acquired IBM personal computers business), Haier (home appliances) and large SOEs, which were merged in the early $2000 \mathrm{~s}^{49}$ and are currently supervised by the State-owned Assets Supervision and Administration Commission of the State Council of China. SINOMACH is one of such SEOs. ${ }^{50}$

Not all of the Chinese companies are the national champions and some of them still use outdated technology. As the Chinese government wants the exports of Chinese machinery and equipment to overtake cheap consumer goods in the export mix, moving up the value chain, as well as wishing to deal with pollution, China encourages its "mature" industries to move offshore. The relocation of such "sunset industries" follows a pattern known as the "international product life cycle", which is a term used by Harvard Professor Raymond Vernon. It encompasses the process, when the country from importing the product starts with the local assembly of imported components, then produces some of the components locally, which turns into export of the product and finally into moving the production process itself due to higher labour costs or pollution. ${ }^{51}$ The government of China encourages outward investment if it meets the requirements of Article 6 of the Outward Investment Sector Direction Policy and 2006 Catalogue of Industries for Guiding Outward Investment. ${ }^{52}$ Article 6 prescribes that the investment will be encouraged if it meets three requirements: first, it can acquire resources or raw materials, for which there is a domestic shortage and an urgent need for the national economic development; second, it can promote the export of domestic products, equipment and technologies with competitive advantages, as well as the export of labour service; third, it can significantly improve China's capacity in technology, research, and development, and can utilize global cutting-edge technologies, advanced management

49 Brautigam, D. The Dragon's Gift: The Real Story of China in Africa. New York: Oxford University Press, 2009, p. 79.

50 List of China's Central CEO [interactive]. [accessed on 03-06-2013]. <http://www.sasac.gov.cn/ n2963340/n2971121/n4956567/4956583.html>.

51 Supra note 49, p. 92-93.

52 Outward Investment Sector Direction Policy \& 2006 Catalogue of Industries for Guiding Outward Investment (NDRC, MOFCOM, Ministry of Foreign Affairs, SAFE \& other entities, July 2006), supra note 45 , p. $75-76$. 
expertise and professionals. Meanwhile, Annex A includes various industries, such as leather, textile, pharmaceuticals, manufacturing of paper and pulp, assembling and manufacturing of machines, trans-border highway and railroad transportation and construction, etc. ${ }^{53}$

Finally, although China has 3.4 trillion USD in foreign reserves, it is mainly in US Treasury bonds, which makes it very susceptible to depreciation of the USD. ${ }^{54}$ In order to diversify such risk and seek higher returns, China uses two sovereign wealth funds to acquire equity investments (portfolio investments): China Investment Corporation, which is responsible for managing part of China's foreign exchange reserves and holds assets worth 482 billion USD ${ }^{55}$, and State Administration of Foreign Exchange (SAFE) Investment Company, which is responsible for managing China's exchange reserves and holds assets worth 567.9 billion USD. ${ }^{56}$ There are two more sovereign wealth funds of China, namely Hong Kong Monetary Authority Investment Portfolio, which manages assets worth 298.7 billion USD, as well as National Social Security Fund, which manages assets worth 160 billion USD, but their purpose is not a diversification of China's foreign reserves, thus they do not work as means for capital export.

\section{Forms of capital export used by China}

Most Chinese companies do not have the same technology or can provide the same quality of goods or services as their counterparts from the developed world. But the Chinese companies can still beat competitors on price and speed. According to the current Twelfth Five-Year Plan, China will be continuing with the "Going Out" strategy guiding enterprises with different ownership to develop overseas investment, especially in cooperation in R\&D technology investment and agricultural sector, outward investment in manufacturing industry and developing overseas project contracts. ${ }^{57}$ Consequently, China encourages its companies to actively seek overseas markets and such support goes either through financing the company in its endeavour abroad or financing the buyer who is willing to buy Chinese goods or services. Moreover, considering its own experience, China encourages its companies to build and operate overseas economic

53 Outward Investment Sector Direction Policy \& 2006 Catalogue of Industries for Guiding Outward Investment (NDRC, MOFCOM, Ministry of Foreign Affairs, SAFE \& other entities, July 2006), supra note 45, p. $75-76$.

54 China Starts Unit to Diversify Reserves from U.S. Debt, WSJ says. Bloomberg News. 21 May 2013 [interactive]. [accessed on 27-05-2013]. <http://www.bloomberg.com/news/2013-05-21/china-startsunit-to-diversify-reserves-from-u-s-debt-wsj-says.html>.

55 SWF Institute's Data on China Investment Corporation [interactive]. [accessed on 25-05-2013]. <http:// www.swfinstitute.org/swfs/china-investment-corporation/>.

56 SWF Institute's Data on SAFE Investment Company [interactive]. [accessed on 25-05-2013]. <http:// www.swfinstitute.org/swfs/safe-investment-company/>.

57 Twelfth Five-Year Plan, 2011-2015, Chapters 52 \& 53. National People's Congress. March 2011. Supra note 45 , p. 12. 
zones, where, if approved, the Chinese companies might receive the financial support from the Chinese government ${ }^{58}$.

China has three "policy banks": China Development Bank, China Export Import Bank (hereinafter - the Eximbank) and China Agricultural Development Bank ${ }^{59}$. Only China Development Bank and the Eximbank participate in the overseas operations.

Analysis of the documents and literature allows classifying the support in the "Going Out" that China provides for its companies in the following categories: special government funds, crediting and aid.

Working paper for the Center for International Forestry Research indicates the following funds, which provide support to Chinese companies investing abroad: resource investment fund, special fund for overseas mining resources risk surveys and special fund for outward economy and technology cooperation ${ }^{60}$. Under the resource investment fund, the China's government allotted special funds to reimburse companies' pre-investment costs in large and medium scale resources and economic and technical cooperation projects related oil resource, non-metal and metal resource projects. The special fund for overseas mining resources risk surveys gives priority to funding mining survey projects with good prospects, large reserves and high expected returns (excluding oil and natural gas). Finally, the outward economy and technology cooperation special fund encourages companies with comparative advantages to develop outward economic and technical cooperation through projects in overseas agriculture, forestry and fishing cooperation, outward project contracting, outward labour services, overseas high-tech research and development, and outward design and consultation. Through this fund, the Chinese companies can get direct funding and subsidies on the interest on credit.

Special government funds are not the only incentive offered for the companies to "go out". The state policy banks provide crediting for the local companies. The Eximbank has an extensive credit system for overseas investment, which includes ${ }^{61}$ export buyer's credit, export seller's credit, import credit, special loans for maritime and aviation sectors, export enterprises fixed assets investment or export base construction loans. The most important ones are the export buyer's credit and the export seller's credit. The export buyer's credit refers to the medium and long-term credit provided to foreign borrowers to finance their imports of Chinese products, technologies and services ${ }^{62}$, which in effect means financing the acquisition of Chinese production. The export seller's credit refers to non-profit loans provided to an exporter to finance its export of manufactured or purchased mechanical and electronic products, complete sets of equipment, and

58 Supra note 49, p. 98.

59 Supra note 49, p. 79.

60 Wenbin, H. and Wilkes, A. Analysis of China's Overseas Investment Policies. Working paper 79. Center for International Forestry Research (CIFOR). 2011, p. 12 [interactive]. [accessed on 05-06-2013]. <http:// www.cifor.org/publications/pdf_files/WPapers/WP-79CIFOR.pdf $>$.

61 Export-Import Bank of China [interactive]. [accessed on 07-06-2013]. <http://english.eximbank.gov. $\mathrm{cn} / \#>$.

62 Export Buyer's Credit [interactive]. [accessed on 07-06-2013]. <http://english.eximbank.gov.cn/businessarticle/activities/buyer/200905/9394_1.html\#>. 
high and new-tech products as well as the provision of labour services ${ }^{63}$. Basically, it provides exporting Chinese companies with otherwise unavailable financial settlement long before the actual payment from the counterparties. Through such direct (financing companies) and indirect (financing buyers) financing of exports, China puts exporters from other countries at disadvantage, even the EU gives note on such practice. ${ }^{64}$

China Development Bank finances mainly domestic infrastructure projects that other banks are less inclined to finance ${ }^{65}$. In regard to overseas operations, China Development Bank is in charge of China-Africa Development Fund, which is its main overseas programme. In addition to that, China Development Bank promotes Chinese investments in global natural resources and infrastructure projects through energybacked loans to foreign governments and national oil companies, financing to Chinese SOEs to support their overseas expansions (M\&As) and investing in Chinese companies that are active abroad through its private equity funds. ${ }^{66}$

Finally, China supports its capital exports through aid. Financial resources provided by China for foreign aid mainly fall into three types: grants (aid grants), interest free loans and concessional loans. The first two types come from China's state finances, whereas concessional loans come through the Eximbank. ${ }^{67}$ According to the White Paper on China's Foreign Aid, grants are used to help recipient countries to build hospitals, schools and low-cost houses, and support well-digging or water-supply projects and other medium and small projects for social welfare, whereas interest-free loans are mainly used to help recipient countries to construct public facilities and launch projects to improve people's livelihood and concessional loans are used to help recipient countries to undertake productive projects generating both economic and social benefits and large and medium-sized infrastructure projects, or to provide complete plant, mechanical and electrical products, technical services and other materials. The concessional loans are of utmost importance and they come into two forms: Chinese government concessional loans and preferential export buyer's credits. The preferential export buyer's credit is the same as the export buyer's credit. The only difference is that the crediting party is not a company, but a country or a region and there is a request of some kind of preferential treatment. The Chinese government concessional loan is a long term and low interest loan to developing country long, to help recipient countries have economic or social benefits with the condition of hiring Chinese companies to perform works. The typical cycle for

63 Export Seller's Credit [interactive]. [accessed on 07-06-2013]. <http://english.eximbank.gov.cn/businessarticle/activities/export/200905/9395_1.html>.

64 Report from the Commission to the European Council: Trade and Investment Barriers Report 2013, p. 8. [interactive]. [accessed on 07-06-2013]. <http://trade.ec.europa.eu/doclib/docs/2013/march/tradoc_150742.pdf $>$.

65 Supra note 49, p. 115.

66 China Development Bank's Overseas Investments: An Assessment of Environmental and Social Policies and Practices. Friends of Earth. 2012 [interactive]. [accessed on 08-06-2013]. <http:// libcloud.s3.amazonaws.com/93/2b/2/2245/China_Development_Banks_overseas_investments_-_An_ assessment_of_environmental_and_social_policies_and_practices.pdf $>$.

67 White Paper on China's Foreign Aid. Information Office of the State Council. April 2011. Supra note 47, p. 14. 
concessional loan project is the following ${ }^{68}$ : Chinese company (usually SOE) suggests the project, the foreign ministry of finance applies for the loan, the Eximbank makes a preliminary appraisal and approves the request, the foreign ministry of finance signs a framework agreement on the terms of the loan with China's Ministry of Commerce and a concessional loan agreement with the Eximbank, the Chinese company then does the work or exports the goods and asks for payment from state-owned company or state, then the company signs off on the request and sends it to the foreign ministry of finance, which, based on such request or on its own, asks the Eximbank to disburse payment to the Chinese company and accepts responsibility for repaying the loan. However, for creditworthy governments with good economic environments and low risk, the Eximbank can issue the loan directly to the borrowing government.

The concessional loans are particularly attractive to developing countries, which due to various reasons, such as the financial crisis of 2007 and the European sovereign debt crisis, which sucked in available financing, might find it difficult to borrow freely in capital markets and which are reluctant to borrow from institutional creditors, such as the International Monetary Fund or major western countries, because their loans usually require either reforms or other commitments.

Considering such forms of support China gives to its Going Out policy, the question arises how the recent news on the relations with CAMCE might be related to the Going Out policy and what is the attractiveness of Lithuania for China's capital exports?

\section{Lithuania as a destination of Chinese capital exports}

According to Dunning, companies that invest abroad can be classified in four categories: natural resource seekers, market seekers, efficiency seekers and strategic asset or capability seekers. ${ }^{69}$ The natural resource seekers invest abroad to acquire particular and specific resources of a high quality at a lower cost than at the home country. Such resource can be physical resources or location-bound resources, such as tourism, car rentals, oil drilling, construction, etc., plentiful supplies of cheap and well-motivated unskilled or semi-skilled labour (usually by manufacturing and service companies with high labour costs) or the need of firms to acquire technological capability, management or marketing expertise and organisational skills. The market seekers invest in a particular country or a region to supply goods or services to markets in these or in adjacent countries because they have to follow the main suppliers or customers and they have to familiarise with the local tastes or needs of the foreign market. Serving a local market from distance is more expensive than production and transaction costs locally, and the company must have a physical presence in the leading markets served by its competitors. The efficiency seekers want to rationalise the structure of established resource-based or market-seeking investment in such a way that the investing company

68 Supra note 49, p. 142.

69 Dunning, J.H. and Lundan, S.M. Multinational Enterprises and the Global Economy. Second edition. Cheltenham: Edvard Elgar Publishing Limited, 2008, p. 68. 
can gain from the common governance of geographically dispersed activities. Finally, the strategic assets seeker acquires the assets of foreign corporations to promote his longterm strategic objectives - augmenting the acquiring firm's global portfolio of physical assets and human competences, which they perceive, will either sustain or strengthen their ownership-specific advantages or weaken those of their competitors.

Although an abundant labour is the asset Lithuania wants foreign investors to exploit, Lithuanian laws that prescribe the minimal wage makes Lithuanian labour expensive compared to the Chinese one and cannot attract natural resource seekers from China. Moreover, the most attractive industries that might be interesting for the Chinese companies looking for world class technology, such as life sciences or laser clusters ${ }^{70}$, have already been acquired by foreign firms (e.g. Fermentas was acquired by Thermo Fishers Scientific, Sicor Biotech was acquired by Teva Pharmaceutical Industries Ltd.) or do not show any interest in takeovers. Finally, the Lithuanian or even the Baltic market is too small to be a reason for the Chinese companies to invest. So, the question arises why China in general or CACMCE in particular is interested in investing in Lithuania?

According to the Twelfth Five-Year Plan, China will encourage foreign investments to develop its middle and western parts. ${ }^{71}$ The development of this region will need accessibility to markets for delivery of natural resources or for exports. As China has the highest volume of rail transport and several rail links to Russia, China is interested in developing and promoting Trans-Asian railway northern corridor, which goes from Lianyungang (China) via Kazakhstan-Russian Federation to Minsk and then to Warsaw and Berlin. ${ }^{72}$ Coincidentally, recently the Lithuanian ambassador to China Mrs. Lina Antanavičienè has also mentioned that for the last four years Lithuania has been successfully cooperating with China in providing common Lithuanian-Chinese transportation initiative in Asia-Europe Meeting. ${ }^{73}$ Lithuania is a logistics country, where logistics accounts for $10.6 \%$ of $\mathrm{GDP}^{74}$. The main transportation companies, which are State Enterprise Klaipèda State Seaport Authority and Lietuvos Gelezinkeliai (national railroad company), belong to the state and have the status of companies that have strategic importance to the national security of Lithuania ${ }^{75}$, therefore, it is not likely that the Lithuanian government will allow equity participation of Chinese companies (by selling shares). As CAMCE does not benefit from transporting goods

70 Promotional Brochure from Invest in Lithuania. P. 19-20 [interactive]. [accessed on 12-06-2013]. <http:// www.investlithuania.com/files/files/PDF/2013\%2006\%2004_Invest\%20Lithuania_general\%20presentation_EUR.pdf?utm_campaign=Apatine+reklamjuoste\&utm_source=www.investlithuania.com\&utm medium=banner>.

71 Supra note 57.

72 Map of Trans-Asian Railway Northern Corridor [interactive]. [accessed on 09-06-2013]. <http://www. unescap.org/ttdw/common/TIS/TAR/images/tarnc_big.gif>.

73 Svarbiausia - Pažinti Kiniją. Eversus. 23 May, 2013. [interactive]. [accessed on 25-05-2013]. <http:// poziuris.eversus.lt/naujienos/2979>.

74 Supra note 70, p. 12.

75 Arts. 3(1)(3) and 4(1)(2) of Law on Enterprises and Facilities of Strategic Importance to National Security and Other Enterprises of Importance to Ensuring National Security of 10 October 2002, No. IX-1132. Official Gazette. 2002, No. 103-4606. 
through Lithuania because it does not have equity interests in neither railroad nor port companies, the question is why Chinese SOE - CAMCE - is interested in transhipment and warehousing complex in Kaunas FEZ? In order to answer this question, attention has to be paid to Belarus.

The CAMCE has been actively engaging in Belarusian economy since 2011, when the CAMCE commenced the project on constructing bleached pulp factory at OJSC Svetlogorsk Pulp and Cardboard Mill. This project was financed by the Eximbank, which gave a 654 million USD loan to the Belarusian government for this purpose. ${ }^{76}$ As the pulp factory was constructed by the CAMCE, but the loan was taken by the Belarusian government, such loan falls under the category of concessional loans. On 11 September, 2011 the Government of the Republic of Belarus and the Government of China concluded an agreement on China-Belarus Industrial Park ${ }^{77}$. According to the notice of Belarusian Telegraph Agency, the CAMCE is one of the operators of this park. ${ }^{78}$ It fits the pattern for China's encouragement of outward investments in overseas economic zones that are built and managed by the Chinese company. Also, the Chinese companies establishing there will have better chances at getting financing through one of the forms of capital exports. The China-Belarus Industrial Park project indicates that the CAMCE should be more interested in investing and promoting this park rather than Kaunas FEZ. However, there are two main differences between Belarus and Lithuania: the former's membership in a regional trade club - European Union, which allows free transportation and export of goods within the single European market, and the technological need to change railroad gauge, which in ex-Soviet countries is $1,520 \mathrm{~mm}$, whereas in Europe it reaches $1,435 \mathrm{~mm}$. Consequently, the combination of railroad, the proximity to Belarus and the membership to the EU are the underlying criteria that explain why the CAMCE might find investing in Lithuania as a point of entry into the EU market.

However, neither the announcement of Ministry of Economy ${ }^{79}$, nor subsequent article $^{80}$ indicates that the CAMCE has obliged to invest in Kaunas FEZ. It simply indicates that the CAMCE is interested in the participation of construction and financing the complex that the CAMCE will be looking for other Chinese companies to invest in Kaunas FEZ and that Kaunas FEZ should cooperate with the China-Belarus Industrial Park. Such early communications without any legally binding documents can easily change. However, considering CAMCE's experience with the bleached pulp factory at OJSC Svetlogorsk Pulp and Cardboard Mill in Belarus, one should not overestimate its potential significance: the CAMCE might be interested in developing Kaunas FEZ

76 Belarus launches bleached pulp project [interactive]. [accessed on 10-06-2013]. <http://www.butb.by/ engl/index.php?page $=49 \& \mathrm{id}=32170>$.

77 Web page of Ministry of Foreign Affairs of the Republic of Belarus [interactive]. [accessed on 12-062013]. <http://mfa.gov.by/en/publications/review/infoprojects/e7707a176160fe53.html>.

78 Notice of Belarusian Telegraph Agency [interactive]. [accessed on 07-06-2013]. <http://news.belta.by/en/ news/econom?id=690930>.

79 Supra note 8.

80 Supra note 9. 
as a contractual partner of Antwerpse Ontwikkelings- en Investeringsmaatschappij NV (A.O.I. NV), the Manager of Kaunas FEZ, in charge of attracting investors from China and as a participant in Kaunas FEZ, using it as the logistical gateway from Belarus to the EU. On the other hand, the CAMCE might be equally interested only in performing works in Lithuania, while such works are financed by the Eximbank through the concessional loan. Such scenario does not meet the needs of Lithuania, which main interest is to attract foreign investor who will create employment instead of acquiring new transhipment and warehousing complex financing it by the loan from China. Therefore, unless the CAMCE builds and operates the multi-purpose transhipment and warehousing complex or assembly line in Kaunas FEZ, there will be discrepancy between the expectancy of the government and the economic reality of the CAMCE.

\section{Evaluation of CAMCE's interests under international investment law}

International investment law does not regulate capital directly or its movement itself. It protects the result of capital movement - foreign investment - and it gives protection only to investments of individuals or corporations, but not to investments of other states. Evaluation of the CAMCE's involvement in Kaunas FEZ from the point of view of international investment law includes assessment on what is considered foreign direct investment under international investment law, whether the status of the CAMCE allows it to be a subject of international investment law and whether current actions of the government of Lithuania have any significance under the international investment law.

Traditionally, international customary law protected only foreign direct investment. For the transaction to qualify as foreign direct investment, there had to be transfer of tangible or intangible assets from one country to another for the purpose of their use in that country to generate wealth under total or partial control of the owner of the asset $^{81}$. According to professors Dolzer and Schreuer, direct investment involves (a) the transfer of funds, (b) a longer-term project, (c) the purpose of regular income, (d) the participation of the person transferring the funds at least to some extent in the management of the project, and (e) a business risk ${ }^{82}$. Such criteria allow distinguishing foreign direct investment from transaction on sale of goods or services or short-term financial transaction ${ }^{83}$. The usual forms of foreign direct investment are a greenfield investment or a merger and acquisition. The greenfield investment is a construction of new operational facilities (factory, warehouse, etc.) from the ground up. Meanwhile, the merger and acquisition is an investment through buying the shares of the existing company. However, not every acquisition of shares constitutes the merger and acquisition

81 Supra note 21, p. 8.

82 Dolzer, R. and Schreuer, C. Principles of International Investment Law. New York: Oxford University Press, 2008, p. 60. 
(i.e. foreign direct investment) because for the transaction to qualify as foreign direct investment one has to acquire control over the company. Therefore, the main difference between foreign direct investment and simple acquisition of shares - which is known as portfolio investment - is control over the company. Only the transaction with shares, which gives the foreigner control over the company, is regarded as foreign direct investment and thus is protected under international investment law.

Notwithstanding to such customary law, countries can provide additional protection for broader scope of transactions that under customary law does not fall under the definition of foreign direct investment. Such protection can be granted through national legislation, investment agreement between investor and state or bilateral investment treaty (hereinafter-BIT). As no investment agreement has been concluded between the CAMCE and Lithuania yet and the definition of investment under Lithuanian national law falls outside the scope of this article, it is necessary to look at what is understood as 'an investment' under China-Lithuania BIT, which provides an 'illustrative' list of 'asset-based' model of what should be regarded as 'an investment ${ }^{\prime 4}$. Article 1 of the Agreement between the Government of the Republic of Lithuania and the Government of the People's Republic of China concerning the Encouragement and Reciprocal Protection of Investment ${ }^{85}$ prescribes that the term 'investment' includes any movable and immovable property and any property rights, shares in companies, claim to money or to any performance having an economic value, intellectual property rights and concessions. Such illustrative list includes not only foreign direct investment, but the portfolio investment, too (by 'shares in companies').

As long as the CAMCE builds and operates transhipment and warehousing (or any other) complex in Kaunas FEZ or establishes a centre to promote Kaunas FEZ in China, such activity would be considered as greenfield investments that fall under customary law definition of foreign direct investment, as well as the definition of 'investment' under China-Lithuania BIT. On the other hand, if the CAMCE just performs the works in Lithuania under the concessional loan from the Eximbank, such economic activity will not be regarded as investment under customary law or China-Lithuania BIT.

Nevertheless, even if CAMCE's activity falls under the notion of 'investment', the international investment law protects only investments made by private individuals or entities and does not protect investments made by the state. The CAMCE is the subsidiary of SINOMACH (China National Machinery Industry) Corporation, i.e. large State-Owned Enterprise, which is administered by the Chinese government through State-owned Assets Supervision and Administration Commission ${ }^{86}$. Such chain of

84 For a more detailed analysis on models of definition of investment and categories of lists of assets and investment types, see Schlemmer, E.C. Investment, Investor, Nationality, and Shareholders. The Oxford Handbook of International Investment Law. New York: Oxford University Press, 2008, p. 49-88.

85 Agreement between the Government of the Republic of Lithuania and the Government of the People's Republic of China concerning the Encouragement and Reciprocal Protection of Investment, dated 8 November 1993 [interactive]. [accessed on 11-06-2013]. <http://unctad.org/sections/dite/iia/docs/bits/ china_lithuania.pdf $>$.

86 Profile page of SINOMACH [interactive]. [accessed on 17-06-2013]. <http://www.sinomach.com.cn/ templates/T_common_en/index.aspx?nodeid=147>. 
control allows concluding that the CAMCE in effect is administered by the Chinese government and thus seems to be unable to receive protection under the international investment law. However, after the CSOB v. Slovakia decision ${ }^{87}$, the mere status of SOE should not preclude the CAMCE from the protection under the international investment law, as long as the activity of the CAMCE is private in nature.

Furthermore, as the potential activity of the CAMCE can be protected under the international investment law, the remaining question concerns qualification of current actions of the Lithuanian government in relation to the international investment law. The international investment law becomes relevant only when the investment is made, with the exception of cases when the respective BIT provides for guarantees in preestablishment phase under the natural standard of treatment clause ${ }^{88}$. However, the actions of the state, which were performed before the investment was made, are relevant in evaluating the violation of 'legitimate expectations' of investor once the investment is made. The phrase 'legitimate expectations' refers to expectations created by host state promises or assurances, which the investment or investor reasonably relies on and which subsequently are infringed. According to Prof. Vandenvelde, such infringement of 'legitimate expectations' or consecutively inconsistent actions compared to the prior promises or assurances of the state constitutes the violation of the fair and equitable standard of treatment ${ }^{89}$. Article 3(1) of the China-Lithuania BIT ${ }^{90}$ provides the fair and equitable standard of treatment, therefore, any promises or assurances given by the Lithuanian government during negotiations with the CAMCE or other Chinese companies might create 'legitimate expectations' that are protected under the international law. Consequently, the officials should be various about such legal consequences and do not provide any formal promises or assurances.

\section{Conclusions}

Lithuania is a capital importing developing state. Although Lithuania's government debt is relatively small, there are economic as well political reasons that suppress Lithuanian government's zeal for borrowing and make the country actively seek for foreign investment. The main economic reason is huge budget deficit of Social Security Fund, which due to political reasons cannot be effectively reduced by cuts on spending. The main political reason is the desire to adopt euro in 2015, which gives additional financial restraints on borrowing. China is one of the biggest capital exporters that promote its companies to invest and export abroad through its Going Out policy. Under

87 ICSID Case No. ARB/97/4, Ceskoslovenska Obchodni Banka, A.S. v. The Slovak Republic. Decision on Objections to Jurisdiction. 24 May, 1999 [interactive]. [accessed on 07-06-2013]. <http://italaw.com/ sites/default/files/case-documents/ita0144.pdf $>$.

88 China-Lithuania BIT does not have such clause.

89 Vandenvelde, K.J. A Unified Theory of Fair and Equitable Standard of Treatment. New York University Journal of International Law and Politics. 2010, 43, 43-106, p. 75.

90 Supra note 85. 
the Going Out policy, China provides various financial incentives for its local companies, as well as for foreign states. Lithuania has no traditional assets that would attract foreign investments from China. However, the combination of railroad, the proximity to Minsk (Belarus) and the membership to the EU allow explaining the underlying reasons for the CAMCE's interest in Kaunas FEZ - Lithuania works as a railway entry point to the EU market from Belarus, where China encourages the development and operation of China-Belarus Industrial Park. Upon the evaluation of information relating to China's forms of encouragement of capital export and CAMCE's activity in Belarus, the CAMCE's interests in Lithuania are not clear yet and can vary from the export of construction services and the creation of additional debt for Lithuania to the investment into transhipment and warehousing complex, assembly line or services to Chinese business centre. For Lithuania to ensure its long term goals, the CAMCE has not only to build operation of investments it will make in Kaunas FEZ, but also to engage in it. International investment law protects only the asset that is transferred from one country to another for the purpose of their use in that country to generate wealth under total or partial control of the owner of the asset. The international investment law does not regulate relations related to the export of services, but it would be applicable for the protection of transhipment and warehousing complex or assembly line in Kaunas FEZ. Finally, the actions of the government of Lithuania seeking to attract the Chinese capital into Lithuania might be relevant in the context of 'legitimate expectations' that Chinese companies might form based under the assurances and promises of the government. Such 'legitimate expectations' are protected under the fair and equitable standard of treatment, therefore, the Lithuanian government should be careful in negotiations with the CAMCE, as any promises or assurances given during such negotiations might create international obligations from which the deviation is not allowed.

\section{References}

Agreement between the Government of the Republic of Lithuania and the Government of the People's Republic of China concerning the Encouragement and Reciprocal Protection of Investment, dated 8 November, 1993 [interactive]. [accessed on 11-062013]. <http://unctad.org/sections/dite/iia/ docs/bits/china_lithuania.pdf $>$.

Resolution No. XII-51 of the Seimas of the Republic of Lithuania on Programme of the Government of Lithuania, dated 13 December, 2012. Official Gazette. 20 December, 2012, No. 149-7630.

Belarus launches bleached pulp project [interactive]. [accessed on 10-06-
2013]. <http://www.butb.by/engl/index. php? page $=49 \& \mathrm{id}=32170>$.

Better Implementation of the "Going Out" Strategy. Announcement of the China's State Council of 15 March, 2006 [interactive]. [accessed on 07-06-2013]. $<$ http://translate.google.lt/translate?sl=zh$\mathrm{CN} \& \mathrm{tl}=\mathrm{en} \&$ prev $=+\mathrm{t} \& \mathrm{hl}=1 \mathrm{t} \& \mathrm{ie}=\mathrm{UTF}-$ $8 \& u=h t t p: / / w w w . g o v . c n / n o d e \_11140 / 2006-$ 03/15/content 227686.htm>.

Brautigam, D. The Dragon's Gift: The Real Story of China in Africa. New York: Oxford University Press, 2009, p. 79.

Capital Dragon Index [interactive]. [accessed on 20-05-2013]. <http://www.acapital.hk/ 
dragonindex/A_CAPITAL_DRAGON_INDEX_FY_2012_ENG.pdf>.

China Development Bank's Overseas Investments: An Assessment of Environmental and Social Policies and Practices. Friends of Earth. 2012 [interactive]. [accessed on 0806-2013]. <http://libcloud.s3.amazonaws. com/93/2b/2/2245/China_Development_ Banks_overseas_investments_-_An_assessment_of_environmental_and_social_policies_and_practices.pdf $>$.

China Starts Unit to Diversify Reserves from U.S. Debt. Bloomberg News. 21 May, 2013 [interactive]. [accessed on 27-05-2013]. $<$ http://www.bloomberg.com/news/201305-21/china-starts-unit-to-diversifyreserves-from-u-s-debt-wsj-says.html>.

Chinese Outward Investment: An Emerging Policy Framework. A Compilation of Primary Sources, p. 2 [interactive]. [accessed on 25-05-2013]. <http://www.iisd.org/ pdf/2012/chinese_outward_investment. pdf $>$.

Consolidated Financial Statement of the Social Security Fund for the Year 2008 [interactive]. [accessed on 03-06-2013]. $<$ http://www.sodra.lt/get.php?f.4863>.

Consolidated Financial Statement of the Social Security Fund for the Year 2009 [interactive]. [accessed on 03-06-2013]. $<$ http://www.sodra.lt/get.php?f.13484>.

Consolidated Financial Statement of the Social Security Fund for the Year 2010 [interactive]. [accessed on 03-06-2013]. $<$ http://www.sodra.lt/get.php?f.20574>.

Consolidated Financial Statement of the Social Security Fund for the Year 2011 [interactive]. [accessed on 03-06-2013]. $<$ http://www.sodra.lt/get.php?f.23319>.

Dolzer, R. and Schreuer, C. Principles of International Investment Law. New York: Oxford University Press, 2008.

EUROSTAT Unemployment News Release. April, 2013 [interactive]. [accessed on 0306-2013]. <http://epp.eurostat.ec.europa.eu/ cache/ITY_PUBLIC/3-31052013-BP/EN/331052013-BP-EN.PDF>.
Export Buyer's Credit [interactive]. [accessed on 07-06-2013]. <http://english.eximbank. gov.cn/businessarticle/activities/buyer/200905/9394_1.html\#>.

Export Seller's Credit [interactive]. [accessed on 07-06-2013]. <http://english.eximbank. gov.cn/businessarticle/activities/export/200905/9395_1.html>.

Export-Import Bank of China [interactive]. [accessed on 07-06-2013]. <http://english.eximbank.gov.cn/\#>.

Deposit and Investment Insurance of 2012. Financial Statement of State Undertaking [interactive]. [accessed on 05-06-2013]. $<$ http://iidraudimas.lt/uploads/documents/ Metine_finansine_2012_2.pdf $>$.

Foreign Direct Investment According to Investor States [interactive]. [accessed on 0306-2013]. <http://www.lb.lt/stat_pub/statbrowser.asp $x$ ? group $=8006$ \&lang $=1 \mathrm{t}>$.

ICSID Case No. ARB/97/4, Ceskoslovenska Obchodni Banka, A.S. v. The Slovak Republic. Decision on Objections to Jurisdiction. 24 May, 1999 [interactive]. [accessed on 0706-2013]. <http://italaw.com/sites/default/ files/case-documents/ita0144.pdf $>$.

ICSID Case No. ARB/06/11, Occidental Petroleum Corporation $v$ The Republic of Ecuador. Award. 5 October, 2012 [interactive]. [accessed on 11-06-2013]. <https://icsid. worldbank.org/ICSID/FrontServlet?request Type $=$ CasesRH\&action $V a l=$ showDoc $\&$ doc $\mathrm{Id}=\mathrm{DC} 2672$ _En\&caseId $=\mathrm{C} 80$ > .

Dunning, J.H. and Lundan, S.M. Multinational Enterprises and the Global Economy. Second edition. Cheltenham: Edvard Elgar Publishing Limited, 2008.

Kauno LEZ Perspektyva - Kinų Pramoninis Miestelis. Verslo žinios. 2013, 79: 6.

Kozlova, A. Capital Export: Past and Trends. Proceedings of the 16th Conference for Junior Researchers „Science - Future of Lithuania " [interactive]. [accessed on 0106-2013]. <http://jmk.vvf.vgtu.lt/index.php/ conference/2013/paper/viewFile/69/112>.

Largest Investor-State Awards 2001-2013. The American Lawyer [interactive]. [accessed on 
19-06-2013]. <http://www.americanlawyer. com/PubArticleTAL.jsp?id=137175289463 9\&slreturn $=20130618070934>$.

Law on Enterprises and Facilities of Strategic Importance to National Security and Other Enterprises of Importance to Ensuring National Security of 10 October, 2002, No. IX-1132. Official Gazette. 2002, No. 1034606.

Lietuvos Darbo Rinka 2013/04 [interactive]. [accessed on 04-06-2013]. <http://www. ldb.lt/Informacija/DarboRinka/Publikacijos/ Attachments/2943/LIETUVOS\%20 DARBO\%20RINKA\%202013-04.pdf $>$.

List of China's Central CEO [interactive]. [accessed on 03-06-2013]. <http://www. sasac.gov.cn/n2963340/n2971121/ n4956567/4956583.html>.

Sornarajah, M. The International Law on Foreign Investment. Third edition. New York: Cambridge University Press, 2012.

Schlemmer, E.C. Investment, Investor, Nationality, and Shareholders. The Oxford Handbook of International Investment Law. New York: Oxford University Press, 2008, p. 49-88.

Map of Trans-Asian Railway Northern Corridor [interactive]. [accessed on 09-06-2013]. $<$ http://www.unescap.org/ttdw/common/ TIS/TAR/images/tarnc_big.gif $>$.

Ministry of Finance of the Republic of Lithuania. General Government Debt by Type of Debt Holder [interactive]. [accessed on 28-052013].<http://www.finmin.lt/finmin.lt/failai/ deficitas/2013/2013IQGGkred.pdf>.

News Announcement. Atverti Keliai Kinijos Kompanijoms Issikurti Kauno LEZ [interactive]. [accessed on 18-05-2013]. <http:// www.ukmin.lt/web/lt/naujienos/naujienos/ atverti_keliai_kinijos_kompanijoms_isikurti_ kauno lez>.

Nice to See You, EU. The Economist. 20 April, 2013. Citing investment fund A CAPITAL.

Nomenclature of the Capital Movement Referred to in Article 1 of the Council Directive 88/361/EEC of 24 June 1988 for the implementation of Article 67 of the
Treaty, [1988] OJ L 178, 08/07/1988 P. $0005-0018$.

Notice of Belarusian Telegraph Agency [interactive]. [accessed on 07-06-2013]. $<$ http://news.belta.by/en/news/econom?id= 690930>.

OECD Code of Liberalisation of Capital Movements [interactive]. [accessed on 2805-2013]. <http://www.oecd.org/daf/inv/ investment-policy/capital\%20movements _ web\%20english.pdf>.

OECD, Economic Surveys CHINA, March 2013, Volume 2013/4, p. 10. [interactive]. [accessed on 20-05-2013]. <http://www. keepeek.com/Digital-Asset-Management/ oecd/economics/oecd-economic-surveyschina-2013_eco_surveys-chn-2013-en>.

Official Notice of the Ministry of Finance [interactive]. [accessed on 28-05-2013]. $<$ http://www.finmin.lt/web/finmin/2013 biudzetas/skolinimasis $>$.

On-line Encyclopaedia Britannica. Capital and Interest [interactive]. [accessed on 02-06-2013].<http://www.britannica. com/EBchecked/topic/93850/capital-andinterest>.

Outward Investment Sector Direction Policy \& 2006 Catalogue of Industries for Guiding Outward Investment (NDRC, MOFCOM, Ministry of Foreign Affairs, SAFE \& other entities, July 2006).

Pasini, F.L. The International Regulatory Regime on Capital Flows. ADBI Working Paper Series No. 338 [interactive]. [accessed on 28-05-2013]. <http://ssrn.com/ abstract $=2065100>$.

Press Release. Commission concludes that Latvia is ready to adopt euro in 2014. [interactive]. [accessed on 04-06-2013]. $<$ http://europa.eu/rapid/press-release_IP-13500_en.htm?locale $=$ en $>$.

Profile page of SINOMACH [interactive]. [accessed on 17-06-2013]. <http://www. sinomach.com.cn/templates/T_common en/index.aspx?nodeid $=147>$.

Promotional Brochure from Invest in Lithuania [interactive]. [accessed on 12-06-2013]. 
$<$ http://www.investlithuania.com/files/files/PDF/2013\%2006\%2004_Invest $\% 20$ Lithuania_general\%20presentation_EUR. pdf?utm_campaign=Apatine + reklamjuo ste\&utm_source=www.investlithuania. com\&utm_medium=banner $>$.

Rapley, J. Understanding Development: Theory and Practice in the Third World. Third edition. London: Lynne Rienner Publishers, Inc., 2007.

Report from the Commission to the European Council: Trade and Investment Barriers Report 2013. [interactive]. [accessed on 0706-2013]. <http://trade.ec.europa.eu/doclib/ docs $/ 2013 / \mathrm{march} /$ tradoc_150742.pdf $>$.

Reports on Implementation of Budget [interactive]. [accessed on 03-06-2013]. $<$ http://www.sodra.lt/lt/veikla/biudzetas $>$.

Research Note, Chinese Investments: Europe vs. the United States [interactive]. [accessed on 22-05-2013]. <http://rhg.com/notes/ chinese-investment-europe-vs-the-unitedstates>.

Resolution No. 153 of the Government of the Republic of Lithuania on Financing the Participation of State Undertaking "Deposit and Investment Insurance" in Transfer of Assets, Rights, Contracts and Obligations of the Bank, dated 20 February 2013. Offcial Gazette. 21 February, 2013, No. 20-966.

Šečkutè, L. and Tvaronavičius, V. Tiesioginių Užsienio Investicijų Baltijos Šalyse Tyrimas. Verslas: Teorija ir Praktika. 2007, 8(3): 153-160.

Statistical Data Portal [interactive]. [accessed on 03-06-2013]. <http://atvira.sodra.lt/>.

Svarbiausia - Pažinti Kiniją. Eversus. 23 May, 2013 [interactive]. [accessed on 25-05-2013]. <http://poziuris.eversus.lt/ naujienos/2979>.

SWF Institute's Data on China Investment Corporation [interactive]. [accessed on 25-
05-2013]. <http://www.swfinstitute.org/ swfs/china-investment-corporation/>.

SWF Institute's Data on SAFE Investment Company [interactive]. [accessed on 25-052013]. <http://www.swfinstitute.org/swfs/ safe-investment-company/>.

The Borrowing of Governmental Sector, Maastricht Criteria [interactive]. [accessed on 30-05-2013]. <http://www. finmin.lt/finmin.lt/failai/deficitas/2013/ PDP2012koreg.pdf $>$.

There were 2,588,418 voters in 2012 parliamentary elections. [interactive]. [accessed on 0506-2013].<http://db1.stat.gov.lt/statbank/ selectvarval/saveselections.asp?MainTable= M3220101\&PLanguage $=0 \&$ TableStyle $=\& B$ uttons $=\&$ PXSId $=20673 \& \mathrm{IQY}=\& \mathrm{TC}=\& \mathrm{ST}=$ ST\&rvar0=\&rvar $1=\&$ rvar $2=\&$ rvar3 $=\&$ rvar 4 $=\&$ rvar $5=\&$ rvar6 $=\& r v a r 7=\&$ rvar $8=\&$ rvar9 $=$ $\& \operatorname{rvar} 10=\& \operatorname{rvar} 11=\& \operatorname{rvar} 12=\& \operatorname{rvar} 13=\& \operatorname{rv}$ $\operatorname{ar} 14=>$.

Vandenvelde, K. J. A Brief History of International Investment Agreements. University of California at Davis Journal of International Law and Policy. 2005, 12: 157-194.

Vandenvelde, K. J. A Unified Theory of Fair and Equitable Standard of Treatment. New York University Journal of International Law and Politics. 2010, 43: 43-106.

Web page of Ministry of Foreign Affairs of the Republic of Belarus [interactive]. [accessed on 12-06-2013]. <http://mfa.gov.by/en/ publications/review/infoprojects/e7707a176160fe53.html>.

Wenbin, H.; Wilkes, A. Analysis of China's Overseas Investment Policies. Working paper 79. Center for International Forestry Research (CIFOR). 2011, p. 12 [interactive]. [accessed on 05-06-2013]. <http://www. cifor.org/publications/pdf_files/WPapers/ WP-79CIFOR.pdf>. 


\title{
KINIJOS PRAKTIKA, SKATINANT KAPITALO EKSPORTĄ, IR JO APSAUGA PAGAL TARPTAUTINĘ INVESTICIJŲ TEISĘ: LIETUVOS ATVEJIS
}

\author{
Andrius Bambalas
}

Mykolo Romerio universitetas, Lietuva

Santrauka. Straipsnio tikslas - apžvelgti, kas yra suprantama kaip kapitalas ir kapitalo judejimas, bei preliminariai įvertinti, kodèl Lietuva importuoja kapitala ir aktyviai siekia pritraukti užsienio investuotojus bei kodèl Kinijos bendrovès apskritai ir vienos iš didžiausiu Kinijoje valstybes imoniu SINOMACH antrine bendrove China CAMC Engineering Co. Ltd. konkrečiai nori importuoti kapitala ja Lietuva. Kapitalas ir jo judejjimas gali büti suprantamas ịvairiai, tačiau siame straipsnyje jis yra analizuojamas per tarptautines investiciju teises prizme - valstybe turi resursa, kurio ji negali išnaudoti apskritai arba negali jo išnaudoti efektyviai. Tuo tarpu užsienio investuotojas turi finansavima, technologijas ar know-how, kuriuos pasitelkus toks resursas gali büti efektyviai išnaudotas. Lietuva yra kapitala importuojanti valstybè, todè siame straipsnyje buvo nustatyta, jog Lietuvos turimas resursas, kurio ji pati negali efektyviai išnaudoti, yra daug darbingo amžiaus ir darbo neturinčì žmoniu, kuriuos valstybe nori, kad užsienio investuotojas įdarbintu ir taip padètu sumažinti finansine našta "Sodros" biudžeto deficitui padengti. Kadangi Kinija yra viena didžiausia kapitalo eksportuotojų, kuri kartu tampa ir viena didžiausiu užsienio investuotoju, siame straipsnyje yra analizuojamos tokio staigaus investiciju srauto iš Kinijos padidejimo priežastys - ejjimo ì išorę politika ir ịvairüs büdai, kuriais Kinija skatina tokia politika. Ivertinus šiuos büdus ir Lietuvos atitiktị bendriems užsienio investuotojus dominantiems kriterijams, buvo nustatyta, kad Kauno LEZ Kinijos įmonei CAMCE gali büti patraukli tik dèl geležinkelio, mažo atstumo iki Minsko ir Lietuvos narystès Europos Sajungoje. Kadangi CAMCE Baltarusijoje vysto laisvaja ekonomine zona Kinijos-Baltarusijos pramones parka, o Kinijos viena iš prioritetiniu pletros sričiu yra Kinijos šiaures vakarinio regiono pletra ir geležinkelio, jungiančio Kiniją ir Vakaru Europa, naudojimas (mařrrutas Lianyungang, Kazachstanas, Rusijos Federacija, Baltarusija), Lietuva ir Kauno LEZ CAMCE gali büti ¿domus tik kaip iejimo i Europos Sajungos bendraja rinka punktas. Kol kas dar nera teisiniu CAMCE įsipareigojimu dèl jos veiklos, informacija pateikiama informaciniuose pranešimuose, todel CAMCE ketinimai gali kisti nuo statybos paslaugu eksporto iki investavimo i perkrovimo ir sandeliavimo komplekso pastatyma irlar valdyma, surinkimo linijos izrengima ar paslaugu Kinijos įmones centro įkürima Kauno LEZ. Tarptautine investiciju teise saugo tik toki kapitala, kuris yra perkeltas is vienos valstybès i kita su tikslu sukurti pajamas, kai tokios pridetinès vertès kürimo metu yra rizika, kapitala eksportuojantis asmuo kontroliuoja toki procesa ir tai yra ilgalaikis kapitalo eksportuotojo isipareigojimas. Tarptautine investiciju teise nereguliuoja santykiu, susijusiu su paslaugu eksportu, tačiau saugotu CAMCE pastatyta ir valdoma pekrovimo ir sandeliavimo kompleksa, surinkimo linija ar Kinijos paslaugu izmonès centra Kauno LEZ. Galiausiai, Lietuvos Respublikos Vyriausybes nariu pastangos, siekiant pritraukti Kinijos investuotojus, tarptautinès investiciju teisès prasme gali büti reikśminga 
aplinkybè vertinant Kinijos kapitala eksportuojančiu i̇moniu teisiu apimti pagal teisinga ir lygiavertị investiciju režimą.

Reikšminiai žodžiai: kapitalo eksportas, tiesioginès investicijos į užsienį, Kinija, ëjimo i išore politika, tarptautine investiciju teisé.

Andrius Bambalas, Mykolo Romerio universiteto Teisès fakulteto Tarptautinès ir Europos Sajungos teisės instituto lektorius. Mokslinių tyrimų kryptys: tarptautinė investicijų teisė, ginčų sprendimas tarptautinëje viešojoje ir privatineje teisẻje, tarptautinè teisè nacionaliniuose teismuose.

Andrius Bambalas, Mykolas Romeris University, Faculty of Law, Institute of International and European Union Law, Lecturer. Research interests: international investment law, dispute resolution in international public and private law, international law in national courts. 